\title{
RETRACTED: STUDY HYDROGEOCHEMISTRY EXPLORATION OF THERMAL SPRING IN RAMSAR AREA, (NORTH OF IRAN)
}

\section{Hamid Reza Samadi ${ }^{1}$}

'Member of Young Researchers Club, Ardestan Branch, Islamic Azad University, Ardestan, Iran

\begin{abstract}
Ramsar area is located across and between Alborze Mountain and Caspine Sea in North of Iran. About 30 spas are located south of the Ramsar and Sadatshar town. They are almost in between 20 to $70 \mathrm{~m}$ elevation. Paleozoic, Mesozoic and Tertiary rocks and alluvial deposit are exposed around the Ramsar area. In tertiary, acidic Plutonism was active and intrusion into the Paleozoic and Cenozoic formations. Quaternary and Alluvium deposits are exposed and extending on the Jurassic formations in Ramsar plain and have thickness lower than $10 \mathrm{~m}$ in show springs. The annual precipitation in the Ramsar region is 976 mm. There has not any proper Thermal spring management in Ramsar area yet. This could post some serious problem on improper management of Thermal spring sites, where its environment has been put into jeopardy. This study aims to provide a way to classify the Thermal springs in Ramsar area. The result of this study help in the classification of Thermal spring sites for official planning improvement of administration and sustainable development of natural resources of the area. The study makes use of the Department of Applied Geosciences in Islamic Azad University. GIS data of a total of 9 Thermal springs in the attempt to set up a classification system of Thermal springs in Ramsar area. These data include surface temperature, conductivity, alkalinity, acidity, $\mathrm{TDS}, \mathrm{pH}$ values, $\mathrm{H} 2 \mathrm{~S}, \mathrm{Ca}, \mathrm{Cl}, \mathrm{Fe}, \mathrm{K}, \mathrm{Mg}, \mathrm{Mn}, \mathrm{Na}$, $\mathrm{SiO} 2, \mathrm{SO} 4$ contents, their locations, usages and other relevant information. The surface temperature of Thermal springs are between $190 \mathrm{C}-650 \mathrm{C}$ and Na-K-Cageothermometer shows estimated reservoir temperature range from 25 o C - 195 o C. Most of the water from these Thermal springs is relatively turbidness and their composition is sodium choloride. The Thermal springs in this area generally exhibit high SiO2 and Na content; strong smell of sulfur. In addition, there are 9 Thermal springs that show high concentration of $\mathrm{Cl}, \mathrm{Ca}, \mathrm{Na}, \mathrm{K}$ and $\mathrm{Mg}$. There are three major criteria used in the classification system in this study, temperature, $p H$ and their usage. On the basis of temperature, there are three classes of Thermal springs in Ramsar area: hyper thermal spring (10\%, 50-99o C); thermal spring (80\%, 30-50o C). There is one class achieved on the basis of $\mathrm{pH}$ values: all of Thermal springs exhibit weak acids. There are 4 types of usage classification: swimming pools, Tourism, space heating and drying of organic materials.
\end{abstract}

Keywords: Hydrogeochemistry, Exploration, Hot spring, Ramsar. 


\section{INTRODUCT ION}

Ramsar area is located across and between Alborze Mountain and Caspine Sea in North of Iran. About 30 spas are located south of the Ramsar and Sadatshar town. They are almost in between 20 to $70 \mathrm{~m}$ elevation. Paleozoic, Mesozoic and Tertiary rocks and alluvial deposit are exposed around the Ramsar area. Quaternary and Alluvium deposits are exposed and extending on the Jurassic formations in Ramsar plain and is composed of fan and debris deposits and have thickness lower than $10 \mathrm{~m}$ in show springs. The annual precipitation in the Ramsar region is $976 \mathrm{~mm}$. Jurassic deposits are composed of conglomerate, sandstone, silt, shale bearing coal lens, marl, and limestone and dolomite units. In tertiary, acidic Plutonism was active and intrusion into the Paleozoic and Cenozoic formations.

Figure-1.Gelogical map of Ramsar area

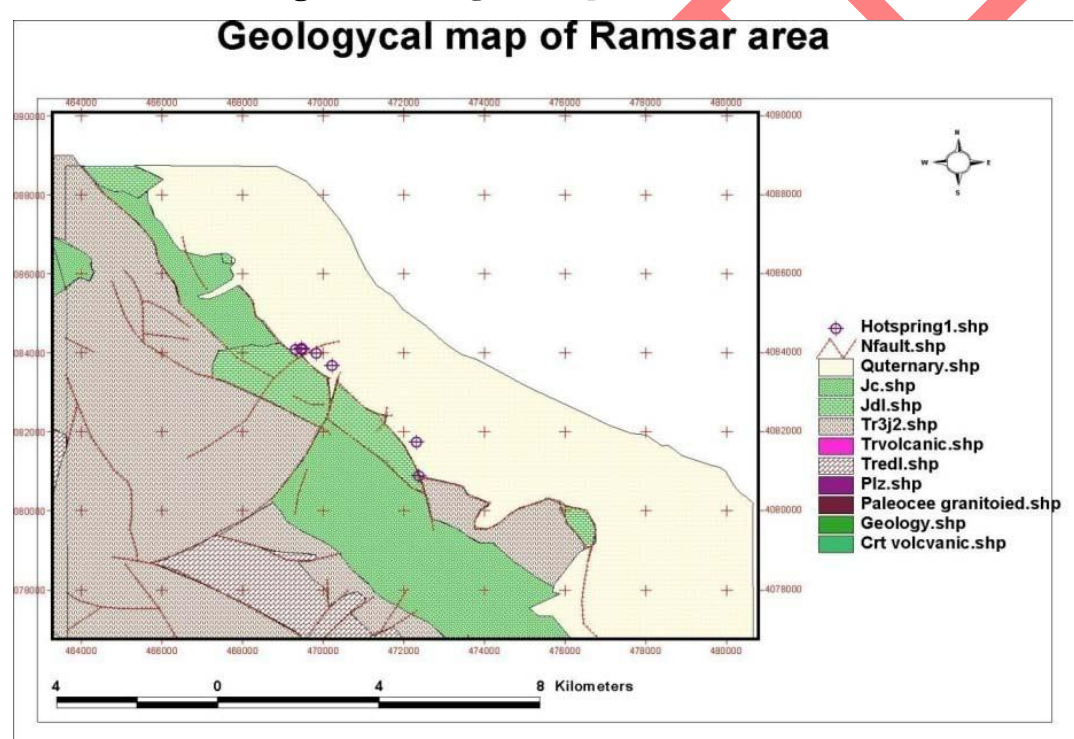

Khazar fault is normally and longest fault in south of Caspine sea, and has NW- SE trend, in junction locally fault with N-S trend and khazar fault thermal waters issue through these faults.

There are increasing of usage of natural resources due to the population growth rate and convenient instruments used in every day life. So there will be serious problems on sustainability and environment. Geothermal resources are one of natural resources, thus sustainable management and wise-used are needed. It is necessary to have information of all geothermal resources in this area. These data providedby BPG programming (BashgahPazhooheshgaran Gavan Islamic azad university of Iran), investigation of thermal spring in Ramsar area. This paper will informs about thermal spring geological settings, geo logy, chemical characteristics of Thermal springs and some classifications of Thermal springs in Ramsar area. 


\section{GEOLOGICAL SETTING}

The Alborz range of northern Iran is a region of active deformation within the broad ArabiaEurasia collision zone. The range is also an excellent example of coeval strike-slip and compress ional deformation, and as such can be an analogue for inactive fold and thrust belts thought to involve a component of oblique shortening (transpressional deformation) (Bunnopas, 1981; Arnorsson and Gudmundsson, 2003). It is roughly $600 \mathrm{~km}$ long and $100 \mathrm{~km}$ across, running along the southern side of the Caspian Sea. Several summits are $.4000 \mathrm{~m}$ in altitude. Damavand, a dormant volcano, reaches $5671 \mathrm{~m}$. The highest non-volcanic summit is AlamKuh, at $4830 \mathrm{~m}$ (Fig. 1).in this part describes the stratigraphy and structural geology of the Alborz range (Figs. 1 and 2). The approach is to integrate many decades of field-based observations by the Geological Survey of Iran with recent seismicity studies (Chonglakmanee et al., 1983; Jarath, 2003).

Outcrops oldest rocks found in this area, including sequence of sandstone, sandy tuff and trachyandesite volcanic rocks equivalent Kahar formation, that non-portion basement rock in Alborz Mountain. This collection with Barot formation only in the south west area and outcrops in the south of region, later Paleozoic rocks equivalent with Lalon\&Mila formations, including shale and sandstone top of anticline in Sehezar and Douhezar Valley are outcrops, that deposits indicated sedimentary environment (Epicontinental Platform) also that affected of tectonic stretching in early stages in Ordovician period (Subtavewung, 2000), existence Dikes and Sills and Alkaline magmatic flow into the sedimentary series, particularly Milla formation in the Sehezar Valley, the confirmation of this claim is. After that oldest formations, appearance Silurian -Devonian volcanic Rocks have wide range of alkaline basalt, trachyandesite, and basic plutonic rocks and indicated for failure phase and complete rifting in oldest platform (Paleotethys Development) While no trace of Devonian sediments has not been in this region. Carboniferous carbonate sediments has not normal base recognizable with oldest formations of any point in the range, also came along with rows carbonate - clastic sediments dependent to Permian and lower middle Triassic unites, this rocks shows relation between continental platform and shallow marine environment (Subtavewung, 2000) in the meantime Progressive and also regressive sea level was formed lateriteic horizons.

The lower member of upper Triassic (Norian) deposit represent shallow marine and Lagoonal environment (section Ekrasar), and to upward exchange to deltaic environment and was formed part of the row about 800 meters of congolomarate (Javaherdeh formation). (Subtavewung, 2000). These sediments belong to Foreland basin, the southern frontal these blocks movement to be raised by reason of Cimmerian orogenic activity. (Subtavewung, 2000). In north and north east of this area, middle-upper Jurassic carbonate sediments non continuous with the Cretaceous sediments. In between these sequences, lack of lower Cretaceous sediments (Neokomian) and Alkaline volcanism activity (post Albion) are shown extent ional activities and influence failed rift, synchronized with compress ional tectonic regime in this region.

In Tertiary granitoied complex was intruded on several time, some of part these rocks in the Eocene time $(2+56$ million years ago) have influence (NushaGranitoied) and cooling them to about 25 million years ago lasted. Other part (AroudGranitoied) intruded about $1+8 / 6$ million 
years ago, and influence of cooling to about 6 million years ago has lasted. (Suensilpong et al., 1978) note, on basis tectonic regime at Eocene to Upper Miocene, about 5 million years ago, in this area uplifted of Alborz range and South basin of Caspian sea is subsidence are suggested. Presence glacier sediments (Moran) a relatively low level flush () and high Quaternary sediments coming torrential refrigerator () to remarkable heights river bed adjacent to the fast rise indicates the region is Quaternary.

\section{CHEMICAL CHARACTERISTICS AND DISTRIBUTION}

There are a total of 9 Thermal springs in Ramsar area. The assay of these Thermal springs consist of surface temperature, conductivity, alkalinity, TDS, $\mathrm{pH}$ values, $\mathrm{H} 2 \mathrm{~S}, \mathrm{Ca}, \mathrm{Cl}, \mathrm{Fe}, \mathrm{K}, \mathrm{Mg}$, $\mathrm{Mn}, \mathrm{Na}, \mathrm{SiO} 2$ and $\mathrm{SO} 4$ contents. The detail of some items is as follow;

\subsection{Surface Temperature}

The temperature measured from a total of 9 Thermal springs range between $19 \mathrm{C}$ and $650 \mathrm{C}$. The average temperature is $440 \mathrm{C}$. The Standard deviation (SD.) is 9 and median (or 50 th \%) is $45 \mathrm{o}$ C. The Thermal springs which, temperature are higher than $650 \mathrm{C}$ mostly located in Ramsar town, probably related to the fault system.

\subsection{Alkalinity (HCO3)}

A total of 9 assay of thermal water show HCO3 content ranging from 442.86 and 7731.08 $\mathrm{mg} / \mathrm{l}$. The average is $1499 \mathrm{mg} / \mathrm{l}$, with an SD. of 24.8 and the median value of $785.56 \mathrm{mg} / \mathrm{l}$. Thermal springs in the northern part of the country have $\mathrm{HCO} 3$ content higher than the average and the median values. It may have been cause by the chemical reaction while thermal water flow through wall rocks which are limestone, dolometic-limestone and dolomite.

\subsection{TDS (Total dissolved solids)}

The 9 thermal water samples have TDS contents between 1356 and $16720 \mathrm{mg} / \mathrm{l}$. The average

is $11210.11 \mathrm{mg} / \mathrm{l}$; the median is $13500 \mathrm{mg} / \mathrm{l}$. Most of TDS in Thermal springs (about $86 \%$ of Thermal springs in the country) are less than $750 \mathrm{mg} / \mathrm{l}$, which is the maximum of standard drinking water, follows by Groundwater acts in 1991. But some of Thermal springs in the south have high TDS $(>1,500 \mathrm{mg} / \mathrm{l})$ especially those Thermal springs located near the junction of NW$\mathrm{SE}$ and N-S faults in Ramsar area. 
Figure-2.Map of TDS in Ramsar area

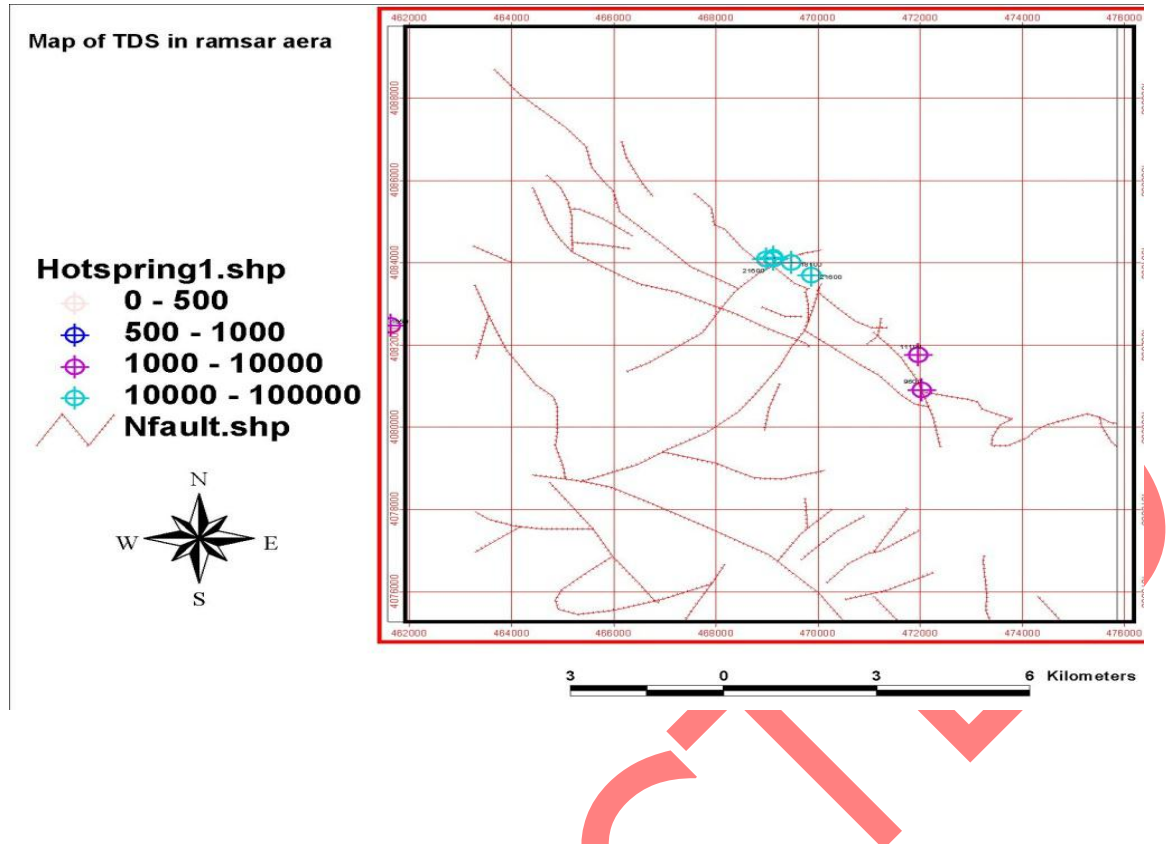

The $\mathrm{pH}$ values of 9 Thermal springs show a range between 5.5 and 6 , with an average of 5.8, the median value of 6 . Most of Thermal springs are weak alkaline.

\subsection{H2S (Sulfide Saturated)}

A total of 26 thermal water samples were analyzed for $\mathrm{H} 2 \mathrm{~S}$. The results show a range between $0.21 \mathrm{mg} / \mathrm{l}$ and $24.6 \mathrm{mg} / \mathrm{l}$, with an average of $5.9 \mathrm{mg} / \mathrm{l}$, an SD of 5.76 and a median value of $4 \mathrm{mg} / \mathrm{l}$. Sulfide smell is slightly strong especially where manifested near granitic rocks. $4.7 \mathrm{Ca}$, $\mathrm{Cl}, \mathrm{K}, \mathrm{Mg}$ and $\mathrm{Na}$. The $\mathrm{Ca}$ content of thermal water has a range between 285948 and 3635254 $\mathrm{mg} / \mathrm{l}$. The average is $922999.7 \mathrm{mg} / \mathrm{l}$, with an SD. Of 319.23 and the median value of 726545 $\mathrm{mg} / \mathrm{l}$. One of the reasons of high $\mathrm{Ca}$ is flowing though gypsum deposits of thermal water (Surat thane Basin) in the south.

Figure-3. K-Mg-Na diagram in the hot sprin of Ramsar

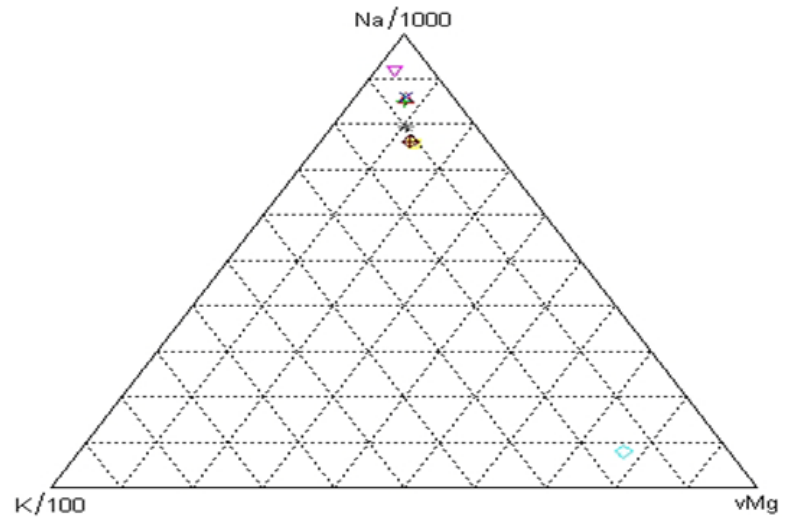


The $\mathrm{Cl}$ content of thermal waters has an assay 16 to $62903 \mathrm{mg} / \mathrm{l}$. The average is about $12636.7 \mathrm{mg} / \mathrm{l}$, with an SD. of 155.06 and the median value of $8961 \mathrm{mg} / \mathrm{l}$. Following Groundwater acts in 1991; standard drinking has $\mathrm{Cl}$ content less than $200 \mathrm{mg} / \mathrm{l}$, brackish water has $\mathrm{Cl}$ content about 1,400-3,000 $\mathrm{mg} / \mathrm{l}$ and salty water has $\mathrm{Cl}$ more than 3,000 $\mathrm{mg} / \mathrm{l}$. Most of Thermal springs in this country has $\mathrm{Cl}$ content less than $200 \mathrm{mg} / \mathrm{l}$.

Figure-4.Mg-Ca-Na diagram in the hot sprin of Ramsar

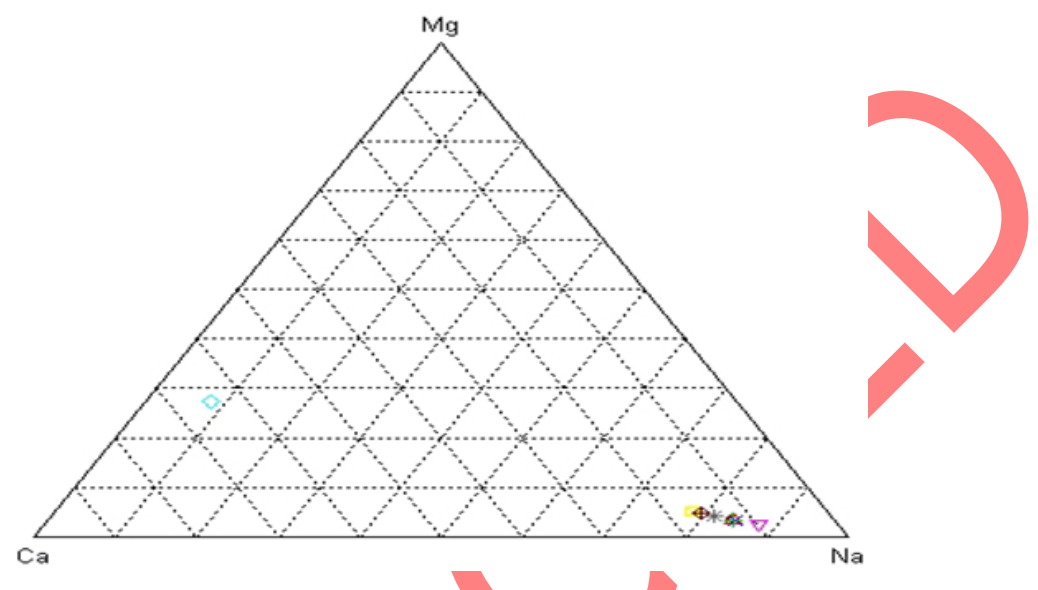

The $\mathrm{K}$ content of thermal water is between 6765 and $187925 \mathrm{mg} / \mathrm{l}$. The average is about51132.33 mg/l, with an SD. of 122.36 and a median value of $42012 \mathrm{mg} / \mathrm{l}$. Most of thermal waters have low $\mathrm{K}$.

The $\mathrm{Mg}$ content of thermal water has arrange between 120886 and $893703 \mathrm{mg} / \mathrm{l}$. The average is about $249722.4 \mathrm{mg} / \mathrm{l}$, with an SD. Of 127.36 and the median value of 202128 .

The Na content of thermal water shows ranging from 35789 to $32600000 \mathrm{mg} / \mathrm{l}$. The average is $6705330 \mathrm{mg} / \mathrm{l}$, with an SD. Of 123.89 and the median value of $4942747 \mathrm{mg} / \mathrm{l}$.

Figure-5.Na-Ca-K diagram in the hot sprin of Ramsar

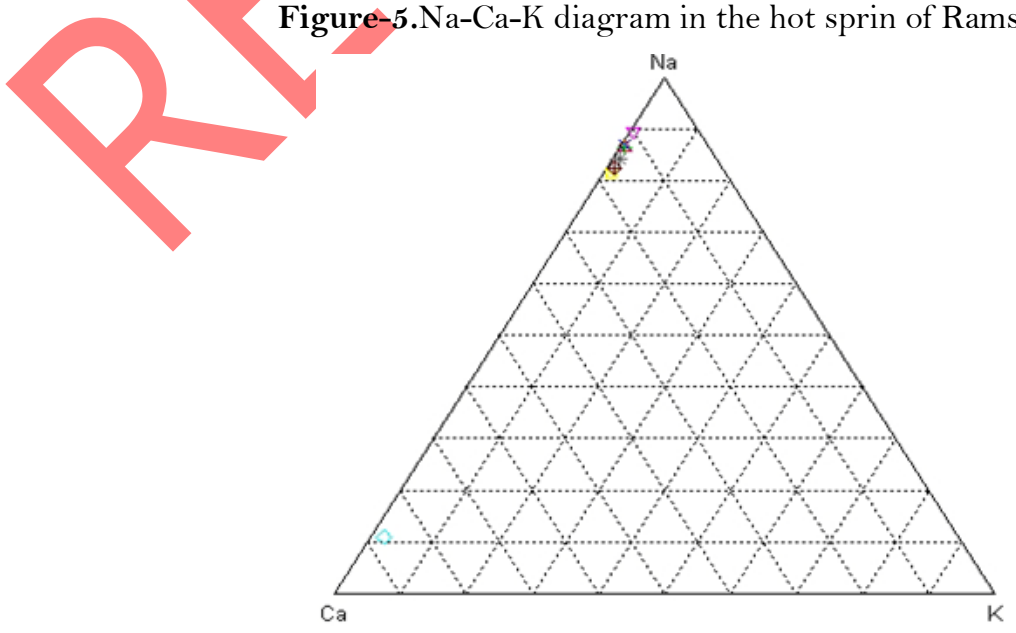


Figure-6.Mg-Ca-Na diagram in the hot sprin of Ramsar

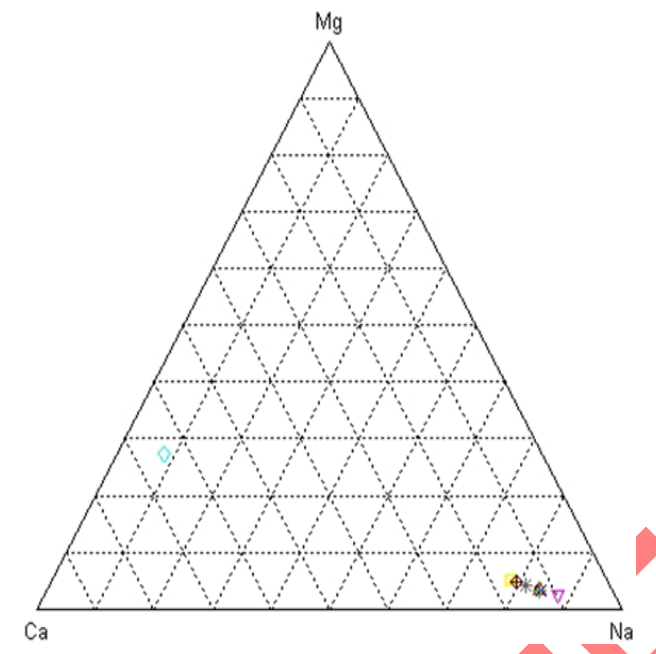

\subsection{Fe (iron)}

The $\mathrm{Fe}$ content of 9 Thermal springs has range from 754 to $8849 \mathrm{mg} / \mathrm{l}$. The average is 2287.33

$\mathrm{mg} / \mathrm{l}$, the $\mathrm{SD}$ is 138.334 and the median is $1311 \mathrm{mg} / \mathrm{l}$. Most of them have Fe content less than $1 \mathrm{mg} / \mathrm{l}$; this value is the standard/drinking water of Groundwater acts in 1991. Only 2 thermal water samples from Mea Hong Son province in the north have Fe content higher than $1 \mathrm{mg} / \mathrm{l}$. To solve high Fe content in the water is to fill oxygen in to water.

\subsection{Mn (manganese)}

The Mn content of 9 Thermal spring samples range from 37.43 to $463.26 \mathrm{mg} / \mathrm{l}$. The average is

about $92 \mathrm{mg} / \mathrm{l}$, the $\mathrm{SD}$ is 91.199 and the median value equals to $46.85 \mathrm{mg} / \mathrm{l}$.

\section{8. $\mathrm{SiO} 2$ (silica)}

A total of 9 assay of thermal water show $\mathrm{SiO} 2$ content from 2.15 to $19 \mathrm{mg} / \mathrm{l}$. The average is $4.36 \mathrm{mg} / \mathrm{l}$, with an SD of 34.05 and a median value of $2.52 \mathrm{mg} / \mathrm{l}$. Thermal springs in the northern part of the country have high $\mathrm{SiO} 2$ content while comparing to Thermal springs in the South.

\section{9. $\mathrm{SO} 4$ (sulfate)}

The SO4 content of 9 Thermal springs has a range between $152 \mathrm{mg} / 1$ and $247.2 \mathrm{mg} / \mathrm{l}$. Theaverage is $204.13 \mathrm{mg} / \mathrm{l}$, with an SD. of 8.06 and a median value of $216.71 \mathrm{mg} / \mathrm{l}$. The Thermal springs having high SO4 are mostly located in the South near the sea especially in Suratthanee, Phang-nga, Krabi and Trang provinces.

Cl-SO4-HCO3 triangular diagram (Giggenbach, 1991) in Figure 3, Ca-Na-K equilibrium triangular diagram and Ca- Na-Mg equilibrium triangular diagram (Hen, 1959; Mitchill, 1981; Giggenbach, 1991) in Figure 4 and Figure 5 present property of thermal water in the Ramsar 
area. Cl-SO4-HCO3 triangular diagram shows that some of thermal water are located on the bicarbonate region such as Safarod and Absiah thermal springs and they are known as ( Peripheral Waters) due to absorobtion of deep $\mathrm{CO} 2$ and to the mixing with shallower water. Most of thermal water property is saline water ocated near the sea in the southern part of the country and a little thermal water are sulfate water which located in the south as well. In Figure 4 and Figure 5 There are approximately $60 \%$ of total number of Thermal springs water samples.On the basis of result from the chemical analysis of $\mathrm{SiO} 2, \mathrm{Na}, \mathrm{K}$ and $\mathrm{Ca}$, the geothermometers were then calculated to estimate reservoir temperature (Fournier, 1981).

The estimated reservoir temperatures from the equations above are summarized in Table 1. Estimated temperature from quartz no stream loss is approximately the same as the temperature obtained from quartz maximum stream loss, where as Na-K-Cageothermometer shows higher estimate temperature and the highest estimate temperature is $\mathrm{Na} / \mathrm{K}$ geothermometer,

\section{CLASSIFICATION OF THERMAL SPRING}

There are many criteria to classify Thermal springs such as temperature, $\mathrm{pH}$, chemicalcomposition etc. These criteria depend on purpose or object of classification. The object of these classifications is to sustainable management and development.

\subsection{Temperature Classification}

There are 4 types of Thermal springs classified by surface temperature as follow; cold spring $<200 \mathrm{C}$

$200 \mathrm{C} \leq$ hypothermal spring $<300 \mathrm{C}$

$300 \mathrm{C} \leq$ thermal spring $<500 \mathrm{C}$

$500 \mathrm{C} \leq$ hyperthermal spring

The one hundred and nine data of Thermal springs in Ramsar indicated that 41 Thermal springs (37\%) are thermal springs, where as 68 Thermal springs (63\%) are hyperthermal springs (Figure $6)$.

\section{2. $\mathrm{pH}$ Classification}

The classification of thermal water based on $\mathrm{pH}$ is divided into 6 classes as follow;

strong acid spring $\mathrm{pH}<2$ acid spring $2 \leq \mathrm{pH}<4$

weak acid spring $4 \leq \mathrm{pH}<6$

neutral spring $6 \leq \mathrm{pH}<7.5$

weak alkaline spring $7.5 \leq \mathrm{pH}<9$

alkaline spring $9 \leq \mathrm{pH}$

Thermal springs in Ramsar are divided into 3 classes on the basis of $\mathrm{pH}$ (Figure 7). These are neutral, weak alkaline and alkaline. Twenty-four percents of Thermal springs show neutral $(\mathrm{pH}=$ $6-7.5)$. Weak alkaline Thermal springs, which have $\mathrm{pH}$ between 7.5 and 9 are found $68 \%$ and $8 \%$ are alkaline Thermal springs $(\mathrm{pH}=9-10)$. 


\subsection{Usage Classification}

There are 4 types of this classification: power plant, Tourism, consumption and unutilized. Geothermal resource in Ramsar are classified in medium enthalpy. There is only one geothermal power plant (300 kW binary cycle) in the north of the country (Fang Geothermal area, Chiang Mai Province). There are approximately $43 \%$ of Thermal springs used in tourism purpose. The consumption of Thermal springs in Ramsar is approximately $17 \%$, where $39 \%$ of Thermal springs in the country is unutilized. It is useful to know status of all Thermal springs, if sustainable development of geothermal are needed.

\section{CONCLUSION}

Most of Thermal springs in Ramsar are classified in sodium bicarbonate, some of them are calcium bicarbonate and others are saline water. In the northern part of the country thermal water generally exhibits strong smell of sulfur and high $\mathrm{SiO} 2$ and $\mathrm{F}$ contents, the reverse is true for those located in the South. The surface temperature is between $190 \mathrm{C}-650 \mathrm{C}$. The $\mathrm{SiO} 2$ geothermometer shows estimated reservoir temperature range from 73 o C - $202 \mathrm{o}$ C. There are three types of Thermal spring classification system; temperature, $\mathrm{pH}$ and geothermal usage. On the basis of temperature, there are two classes of Thermal springs in Ramsar: $62 \%$ of Thermal spring are hyperthermal spring (50-99o C) and 38\% show thermal spring (30-50o C). There are three classes achieved on the basis of $\mathrm{pH}$ values: $68 \%$ of Thermal springs exhibit weak alkaline (7.5-9), 24\% show neutral (6-7.5) and $8 \%$ are alkaline (9-10) springs. The last classification is geothermal usage. They are classified in 4 types: power plant (only one Thermal spring), tourism (43\%), consumption $(17 \%)$ and unutilized (39\%). The most popularity use of Thermal spring trend in Ramsar is Thermal spring spa business.

Funding: This study received no specific financial support.

Competing Interests: The author declares that there are no conflicts of interests regarding the publication of this paper.

\section{REFERENCES}

Arnorsson, S. and B.T. Gudmundsson, 2003. Geochemical monitoring of the response of geothermal, reservoirs to production load examples from KraflaIceland. Proceedings International Geothermal Conference, Reykjavik, Iceland. pp: 30-36.

Bunnopas, S., 1981. Paleogeographic history of westernThailand and adjacent part of Southeast Asia: A platetectonic interpretation. Unpublished PhD Thesis, victory University of Wellington, New Zealand, (reprinted in 1982, as geological survey paper, no. 5, geological survey division, Royal Thai Department of Mineral Resources, Bangkok, Thailand). pp: 81.

Chonglakmanee, C., S. Bunnopas, A. Charoenpravat, Nakinbodee, N. Nakornsri, D. P. and S. Sarapirome, 1983. Geological map of division, Royal Thai Department of Mineral Resources, Bangkok (5 sheets). 
Fournier, R.O., 1981. Application of water geochemistry exploration and reservoir engineering, in Rybach, L., and Muffler, L.J.P., eds.,Geothermal system,:Principle and case histories, New York John Wiley \&Sons Inc.

Giggenbach, W.F., 1991. Chemical techniques. In Application of geochemistry in geothermal reservoir development, (Ed) D’Amore, United Nation Institute for Training and Research, USA.

Hen, J.D., 1959. Study and interpretation of the chemical characteristics of natural water. Geological Survey water supply paper.

Jarath, W., 2003. Chemical properties of hot springs in Thailand. Analysis Division, Department of Mineral Resources, Bangkok, Thailand. pp: 80.

Mitchill, A.H.G., 1981. Phanerozoic plate boundaries in mainland SE Asia, the Himalayas and Tibet. Geological Society of London Journal, 138: 109-122.

Subtavewung, P., 2000. Geothermal energy in Thailand.Country report present to training course in Geothermal energy and environmental sciences (JFY2000), JAPAN. pp: 47-49.

Suensilpong, S., C.K. Burton, N. Mantachit and D.R. Workman, 1978. Geological evaluation and igneous activity of thailand and adjacent areas, episodes geological newsletter, international union of geological science, $178(3)$ : 12-18.

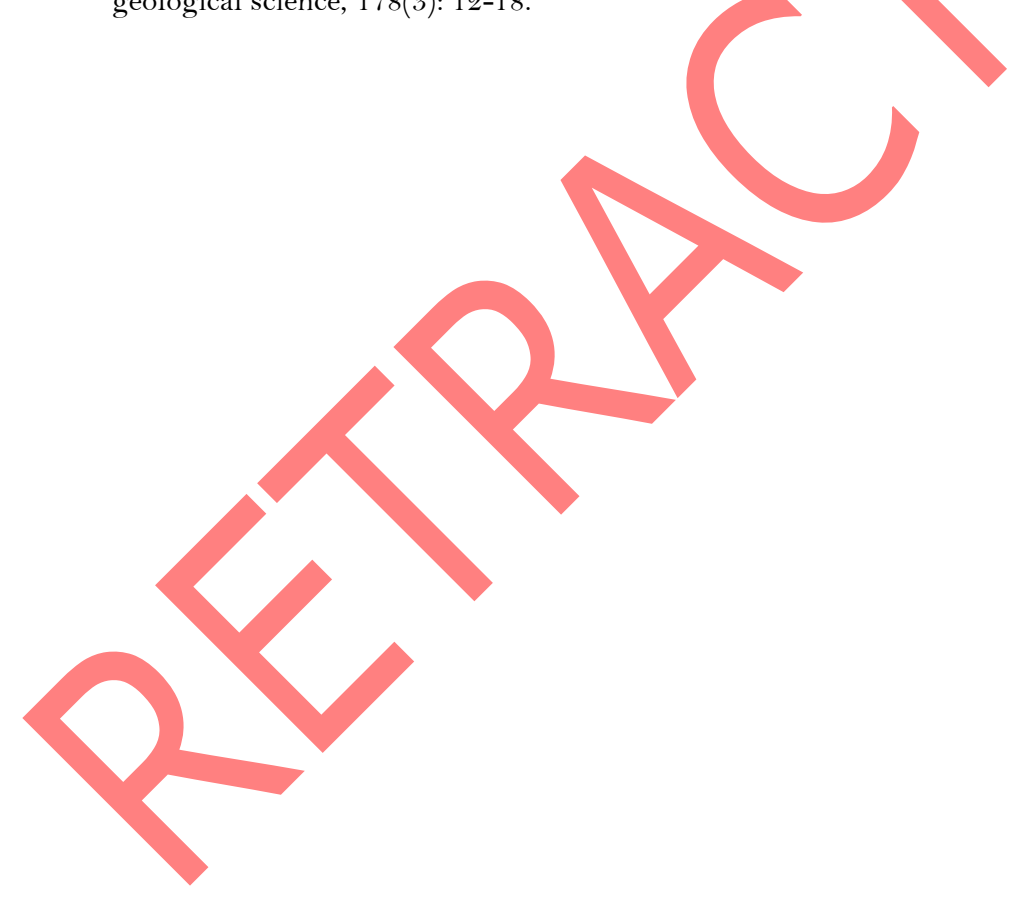

